\title{
Pengaruh PDB, Inflasi, Kurs Dan Tingkat Suku BungaTerhadap Neraca Perdagangan Indonesia
}

\author{
Ilham Tri Murdo, ${ }^{1)}$ Junaidi Affan ${ }^{2)}$ \\ Program Studi Manajemen Sekolah Tinggi Ilmu Ekonomi „SBI ${ }^{e c}$ Yogyakartaemail: \\ ilhamtrimurdo@gmail.com \\ email: junaidiaffan@gmail.com
}

\begin{abstract}
This study is to determine the extent to which the independent variable factors (GDP, Inflation, Exchange and Interest Rates) affect the dependent variable (Trade Balance) in the last 20 years. Quantitative research aims to obtain empirical evidence regarding the effect of the variables of GDP, Inflation, Exchange Rates and Interest Rates on the Trade Balance, and also to test hypotheses to strengthen or even reject the hypothesis. With the following results: GDP has a negative and insignificant effect on the Trade Balance, Inflation has a negative and significant effect on the Trade Balance, the Exchange Rate has no and no significant effect on the Trade Balance, Interest Rates have no and no significant effect on the Trade Balance and GDP, INflation, Exchange and Interest Rates together (simultaneously) have a significant and significant effect on the Trade Balance
\end{abstract}

Keywords: GDP, Inflation, Exchange, Interest Rate, Trade Balance

Penelitian ini untuk mengetahui sejauh mana faktor-faktor variable indipenden (PDB, Inflasi, Kurs dan Tingkat Suku Bunga) mempengaruhi variable dependen (Neraca Perdagangan) dalam kurun waktu 20 tahun terakhir. penelitian kuantitatif bertujuan untuk memperoleh bukti empiris mengenai pengaruh variable PDB, Inflasi, Nilai Tukar dan Tingkat Suku Bunga terhadap Neraca Perdagangan, dan juga menguji hipotesis guna memperkuat atau bahkan menolak hipotesis. Dengan hasil sebagai berikut : PDB berpengaruh negatif dan tidak signifikan terhadap Neraca Perdagangan, Inflasi berpengaruh negatif dan signifikan terhadap terhadap Neraca Perdagangan, Kurs tidak berpengaruhdan tidak signifikan terhadap Neraca Perdagangan, Tingkat Suku Bunga tidak berpengaruh dan tidak signifikan terhadap Neraca Perdagangan dan PDB, INflasi, Kurs dan Tingkat Suku Bunga secara bersama-sama (simultan) berpengaruh dan signifikan terhadap Neraca Perdagangan

Keywords: PDB, Inflasi, Kurs, Tingkat Suku Bunga, Neraca Perdagangan 


\section{Ilham Tri Murdo, Junaidi Affan}

\section{A. PENDAHULUAN}

Neraca Perdagangan adalah suatu catatan atau ikhtisar yang memuat atau mencatat semuatransaksi ekspor dan transaki impor suatu negara atau rincian laba rugi pada jangka waktu tertentu yang menunjukkan selisih antara nilai transaksi ekspor dan transaksi impor dalan suatu Negara dalam jangka waktu tertentu. Dalam perekonomian suatu negara, neraca perdagangan mempunyai pengaruh dan kontribusi dalam penambahan atau pengurangan terhadap pendapatan nasionalnya. Akan memberikan tambahan yang positif jika mengalami surplus perdagangan, yaitu jumlah ekspor dalam satu periode lebih besar dari jumlah impornya. Begitu juga akan mengurangi pendapatan nasional jika mengalami defisit perdagangan, yaitu jumlah ekspor dalam 1 periode lebih sedikit di banding dengan jumlah impor.

Dalam kurun waktu 2 dekade terakhir, neraca perdagangan Indonesia mengalami fluktuasi dan kecenderungan (tren) mengalami penurunan. Pada tahun 2000 neraca perdagangan tercatat surplus sebesar US\$20,609.20 million, kemudian bergerak relatif stabil pada angka kisaran US\$ 25,000-28,000 million, dan meningkat pada tahun 2006-2007 sebesar kisaran US\$ 39,000 million lebih sedikit. Pada tahun 2008 neraca perdagangan mengalami penurunan yang sangat drastis, meskipun tidak terjadi defisit menjadi US\$ 7,823.10, ini dikarenakan terjadinya krisis global tahun 2007-2008. Neraca Perdagangan Indonesia mengalami penurunan karena peningkatan ekspor lebih rendah dibandingkan dengan peningkatan impor, sebagai efek darimelemahnya permintaan global. Memasuki tahun 2009, pemerintah berhasil keluar dari krisis, dengan kebijakankebijakan yang di ambil seperti 10 arahan presiden (direktif presiden RI) dan lainnya (Bapennas, 2009), yang kemudian transaksi neraca perdagangan kembali membaik denganmencatat kenaikan surplus menjadi US\$ 19,680.80 million dan kembali naik menjadi US\$26,060 million pada tahun 2011, sebelum kemudian terjadi defisit tiga tahun berturut-turut tahun $2012-2014$.

\section{Gambar 1 Perkembangan Neraca Perdagangan Tahun 2000-2019}

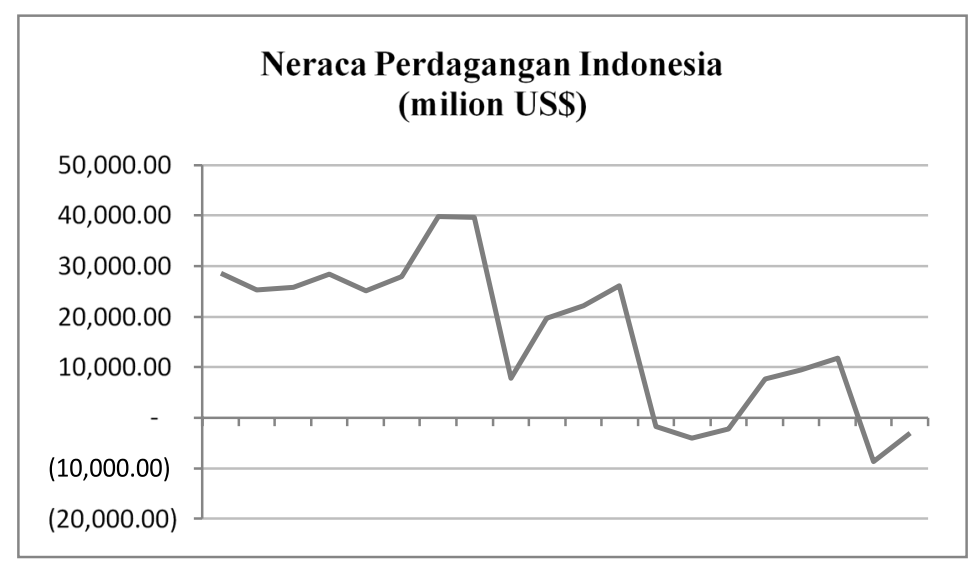

Sumber : BPS : 2020

$176 .:$. $\quad$ Jurnal Solusi, Volume 16, Nomor 2, Desember 202I | P 1907-2376, E 2797-8699 
Memasuki tahun 2012, neraca perdagangan mengalami defisit US\$ 1,670.70 million, meningkat lagi menjadi tahun 2013 sebesar US\$ 4,076.90 million dan kembali defisit, meskipun lebih kecil tahun 2014 menjadi 2,198.80 million. Defisit nilai perdagangan tersebut disebabkan oleh salah satunya defisit komodity minyak dan gas dan impor mencapai US\$33,59 million dan nilai ekspor sebesar US\$23,85 million, karena komoditi non migas masih surplus sebesar US\$ 0,49 million (BPS:2013). Pada tahun 2015 sampai 2017, neraca perdagangan kembali naik menjadi surplus sebesar US\$ 7,671.80 million, US\$ 9,481.20 million dan US\$ $11,842.70$ million, sebelum akhirnya mengalami defisit pada tahun 2018 dan 2019 sebesar US\$ 8,698.50 million dan US $\$ 3,044.40$ million, penyebabnya adalah adanya defisit migas $44,2 \%$ dan anjlognya surplus non migas sebesar 81,4\% (merdeka.com : 2019).

Keadaan surplus maupun defisit neraca perdagangan, tergantung dari jumlah ekspor yang dilakukan oleh suatu negara dalam kurun waktu 1periode (tahun), setelah di kurangi jumlah impornya dalam kurun waktu yang sama. Jika selisihnya positif (Ekspor - Impor), maka neraca perdagangan memperoleh surplus begitu juga sebaliknya, semakin besar selisih positif akan semakin baik, memberikan kontribusi yang semakin baik (bertambah) pada pendapatan nasional negara tersebut dalam tahun berjalan. Perkembangan Ekspor Indonesia pada kurung waktu 2 dekade (2000-2019), terlihat mempunyai kecenderungan (trend) meningkat.

\section{Gambar 2 Perkembangan Ekspor Impor Indonesia Tahun 2000-2019}

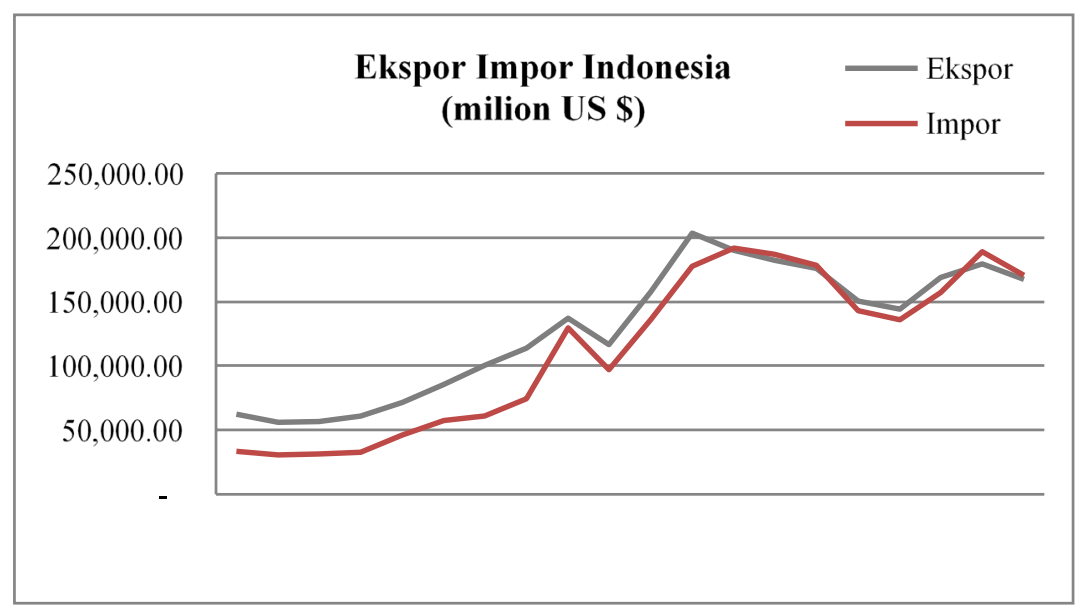

Sumber : BPS : 2020

Perkembangan ekspor secara keseluruhan menunjukkan kenaikan yang cukup tinggi sampai puncaknya pada tahun 2011 mencapai US\$ 203,496.60 million di dibanding pada tahun 2000 sebesar US\$ 62,124,00 million. Meskipun sesudahnya mengalami penurunan sampai tahun 2016, naik sedikit pada tahun 2017-2018 dan sedikit menurun pada tahun 2019. Komponen Ekspor tidak lagi di dominasi dari migas, 


\section{Ilham Tri Murdo, Junaidi Affan}

rata-rata ekspor migas hanya menyumbang sekitar 20\%- 30\%, sedangkan sisanya oleh ekspor non migas. Sedangkan perkembangan Impor hampir sama kenaikannya dengan ekspor, yang membedakan adalah selisih/gap semakin menyempit dan bahkan tahun 2012-2014 serta tahun 2018-2019 jumlah impor lebih banyak sedikit di banding ekspor. Komponen impor yang paling dominan adalah bahan baku sebesar $75 \%$ dari keseluruhan impor, sisanya barang konsumsi 9\% dan sisanya barang modal.

Faktor lain yang terkait dengan neraca perdagangan, adalah pendapatan nasional yaitu jumlah barang-barang dan jasa-jasa yang di hasilkan oleh suatu Negara dalam satu periode (tahun), jika perkembangan pendapatan nasional semakin meningkat, artinya jumlah barang- barang dan jasa-jasa yang di hasilkan juga meningkat, jika ini berlangsung maka akan ada kelebihan barang-barang dan jasa-jasa di dalam negeri yang tidak terserap pasar akan di jual ke luar negeri, dengan demikian bisa meningkatkan ekspor, selain memperoleh devisa juga akan menambah pendapatan nasional. Di sisi lain pemerintah juga berusaha secara maksimal untuk mengatur dan mengendalikan jumlah impor, jangan sampai terjadi defisist neraca perdagangan. Jika tidak bisa mengatur dan mengendalikan maka usaha dari meningkatkan pendapatan akan menjadi sia-sia karena akan menjadi defisit neraca perdagangan yang akan mengurangi jumlah pendapatan nasional tahun berjalan.

Kecenderungan harga-harga yang meningkat (inflasi) akan memberikan pengaruh terhadap Ekspor, jika harga-harga naik menyebabkan biaya faktor produksi akan mengalami kenaikan yang berimbas pada harga barang dan jasa yang dihasilkan juga berpotensi mengalami kenaikan, disisi lain tingkat pendapatan dalam jangka pendek tidak serta merta bisa mengikuti harga-harga dan jasa-jasa yang dihasilkan, ataupun jika terjadi kenaikan tidak sebanding dengan kenaikan harga (inflasi) tersebut. Inflasi menyebabkan produsen akan mengurangi produksi barang-barang dan jasa-jasa menyesuaikan keseimbangan atas permintaan yang menurun, dengan berkurangnya produksi barang-barang dan jasa-jasa akibatnya jumlah barang-barang dan jasa-jasa yang di jual ke luar negeri (ekspor) juga mengalami penurunan, disamping harga barangbarang dan jasa-jasa yang mengalami kenaikan akibat inflasi tidak bisa bersaing dengan produk-produk yang dihasilkan oleh negara lain karena harga lebih mahal.

Kurs atau nilai tukar mata uang suatu negara dapat mempengaruhi kinerja ekspor, jika nilai tukar mata uang (kurs) mengalami pelemahan (nilai nominal meningkat) terhadap mata uang asing utama (US\$), menyebabkan kinerja ekspor akan mengalami kenaikan, hal ini termotivasi dengan harga yang sama atas barang-barang dan jasa-jasa di luar negeri dengan mata uang asing utama (US\$) akan memberikan nilai nominal yang lebih besar jika di tukarkan dengan dengan mata uang dalam negeri (rupiah). Di sisi lain jumlah impor akan mengalami penurunan, karena harga-harga barang impor akan lebih mahal dengan mata uang (rupiah), meskipun harga barang- barang impor tersebut tidak mengalami kenaikan (tetap) berdasar mata uang asing (US\$).

Tingkat suku bunga yang rendah akan menyebabkan menurunnya cost of capital atau biaya modal, sehingga sumber-sumber pendanaan menjadi murah akibatnya 
banyak perusahaan menggunakan dana yang murah untuk melakukan ekspansi atau investasi dalam meningkatkan barang dan jasa yang di hasilkan, yang diikuti pula dengan kondisi ekonomi yang membaik. Dengan bertambahnya investasi selain bisa memberikan kesempatan kerja, juga menghasilkan barang-barang dan jasa-jasa lebih banyak untuk memenuhi kebutuhan baik pasar dalam negeri maupun pasar luar negeri, sehingga kegiatan ekspor juga mengalami peningkatan seiring dengan bertambahnya jumlah barang-barang dan jasajasa yang di hasilkan tersebut.

Selanjutnya berdasarkan latar belakang tersebut di atas, sangat menarik untuk dilakukan kajian secara mendalam dengan melakukan penelitian untuk memperoleh jawaban secara empiris tentang faktor-faktor yang mempengaruhi neraca perdagangan, yaiutu pendapatan nasional/produk domestic bruto (PDB), kenaikan tingkat harga (inflasi), kurs atau nilai tukar mata uang (rupiah) terhadap US\$, dan tingkat suku bunga yang berlaku di Indonesia, sehingga judul yang bisa dikemukakan adalah pengaruh Produk Domestik Bruto (PDB), Inflasi, Kurs, dan Tingkat Suku Bunga Terhadap Neraca Perdagangan Indonesia.

\section{B. KERANGKA TEORITIS DAN PENGEMBANGAN HIPOTESIS}

1. Tinjauan Pustaka

a. Neraca Perdagangan

1) Pengertian

- suatu catatan atau ikhtisar yang memuat atau mencatat semua transaksi ekspor dantransaksi impor suatu negara.

- rincian laba rugi pada jangka waktu tertentu yang menunjukkan selisih antara nilaitransaksi ekspor dan impor suatu negara dalam jangka waktu tertentu.

- $\quad$ suatu catatan ekspor dan impor barang maupun jasa dalam suatu negara dalamjangka waktu tertentu.

- perbedaan antara nilai semua barang dan jasa yang diekspor dan diimpor dari suatunegara dalam periode waktu tertentu

2) Surplus Neraca Perdagangan

Suatu keadaan di mana nilai ekspor keseluruhan suatu negara dalam satu periode lebihbesar dari pada nilai impornya.

3) Defisit Neraca Perdagangan

Suatu keadaan di mana nilai ekspor keseluruhan suatu negara dalam satu periode lebihkecil dari pada nilai impornya.

b. Ekspor

1) Pengertian

- Penjualan barang dan jasa yang dihasilkan suatu negara ken agar lainnya, terdiri dari barang berwujud dan jasa-jasa. 
- Kegiatan perdagangan inetrnasional yang memberi rangsangan guna menumbuhkan permintaan dalam negeri yang menyebabkan tumbuhnya industry industry pabrik besar, bersamaan dengan struktur positif yang stabil dan lembaga sosial yang efisien (Todaro :2000)

- barang dan jasa yang diproduksi di dalam negeri dan dijual di luar negeri"e. (Mankiw :2006)

- perdagangan dengan cara mengeluarkan barang dari dalam keluar wilayah Pabean (Statistik Perdagangan Indonesia)

- salah satu sektor perekonomian yang memegang peranan penting dan melalui perluasan pasar sektor industri akan mendorong sektor industri lainnya dan perekonomian"e (Meier :1996)

2) Peranan Ekspor dalam Neraca Perdagangan

- Jika nilai ekspor di suatu dalam satu periode melebihi nilai impornya, maka neraca perdagangan mengalami surplus dan akan menambah pendapatan nasional.

- Jika nilai ekspor di suatu dalam satu periode lebih kecil dari nilai impornya, maka neraca perdagangan mengalami defisit dan akan mengurangi pendapatan nasional.

- Pemerintah berusaha meningkatkan ekspor, dengan mengurangi impor atau meningkatkan impor tidak melebihi peningkatan ekspor, atau prosentase peningkatan ekspor lebih besar di banding prosentase peningkatan impor.

c. Impor

1) Pengertian

- Kegiatan memasukan barang dari luar wilayah Indonesia atau luar daerah pabean ke dalam wilayah Indonesia atau daerah pabean (Susilo : 2013).

- kegiatan memasukan barang dari luar daerah Indonesia atau dikenal juga dengan sebutan daerah pabean kedalam daerah Indonesia atau daerah pabean (Berata : 2013)

- merupakan kegiatan memasukan barang kedalam daerah pabean baik yang dilakukan oleh orang pribadi maupun badan hukum yang dibawa oleh sarana pengangkut telah melintasi batas Negara dan kepadanya diwaijibkan memenuhi kewajiban pabean seperti,pembayaran bea masuk dan pajak dalam rangka impor. (Indriyani : 2015) 
- kegiatan memasukkan barang ke dalam daerah pabean (UU Nomor 17 Tahun 2006)

2) Peranan Impor dalam Neraca Perdagangan

- Impor di suatu Negara dalam satu periode nilainya tidak melebihi ekspornya, menunjukkan bahwa neraca perdagangan Negara tersebut mengalami surplus yang bisamenambah pendapatan nasional.

- Untuk menjaga neraca perdagangan suatu negara dalam posisi surplus, maka pemerintah wajib berusaha untuk meningkatkan ekspornya dan menjaga dan mengendalikan kegiatan impornya.

d. Pendapatan Nasional

1) Pengertian

- pendapatan nasional adalah jumlah pendapatan yang diterima oleh faktor-faktor produksi yang digunakan untuk memproduksikan barang dan jasa dalam suatu tahun tertentu. (sukirno : 2016)

- pendapatan nasional adalah tenaga kerja dan modal dari suatu negara yang mengolah sumber alamnya untuk memproduksi sejumlah netto komoditi, baik material dan immaterial, termasuk jasa dan sejenisnya.(Alfred Marshall)

- Pendapatan nasional merupakan salah satu indikator penting untuk mengetahui kondisi ekonomi disuatu negara dalam periode tertentu. Pendapatan nasional adalah PDB, baik atas dasar harga berlaku maupun atas dasar harga konstan.

2) Konsep Pendapatan Nasional

- Produk Domestik Bruto (Gross Domestic Product), Keseluruhan nilai barang-barang dan jasa-jasa yang (diproduksi di dalam negeri oleh faktor-faktor produksi dalam negeri maupun luar negeri) dalam satu periode.

- Produk Nasional Bruto (Gross National Product), Keseluruhan nilai barang-barang dan jasa-jasa yang (diproduksi oleh faktor-faktor produksi dalam negeri baik di dalam negeri maupun luar negeri) dalam satu periode.

- Pendapatan Nasional (National Income), Jumlah dari pendapatan faktor-faktor produksiyang digunakan untuk memproduksi barangbarang dan jasa-jasa dalam suatu negara dalam satu tahun.

3) Hubungan Pendapatan Nasional dengan Neraca Perdagangan

Dari pengertian neraca perdagangan di atas, adalah suatu catatan atau ikhtisar yang memuat atau mencatat semua transaksi ekspor dan transaksi impor suatu negara, artinya hanya di hirung besaran Ekspor (X) 
dan Impor (M) suatu negara dalam satu periode. Dalam pendapatan nasional yang dihitung dengan cara pengeluaran maka $\mathrm{Y}=\mathrm{C}$ $+\mathrm{I}+\mathrm{G}+(\mathrm{X}-\mathrm{M})$, sehingga jika terjadi deficit neraca perdagangan akan mengurangi jumlah pendapatan nasionalnya dan jika terjadi surplus akan menambag pendaatan nasionalnya.

e.. Nilai Tukar Mata Uang (Kurs)

1) Pengertian

- Merupajan harga rupiah terhadap mata uang asing. Nilai mata uang rupiah yang ditukar dengan mata uang Negara lain disebut nilai tukar rupiah

- Jumlah dari mata uang suatu Negara yang dapat ditukarkan per unit dari mata uang Negara lain (Adiningsih : 2022)

- Nilai tukar mata uang (exchange rate) atau sering disebut kurs merupakan harga mata uang terhadap mata uang lainnya. Kurs merupakan salah satu harga yang terpenting dalam perekonomian terbuka mengingat pengaruh yang demikian besar bagi neraca transaksi berjalan maupun variabelvariabel makro ekonomi yang lainnya".(Sukirno : 2011)

- "Harga di dalam pertukaran dua macam mata uang yang berbeda, akan terdapat perbandingan nilai atau harga antara kedua mata uang tertentu, perbandingan nilai inilah yang disebut exchange rate". (Nopirin:2012)

- $\quad$ Kurs merupakan harga suatu mata uang relatif terhadap mata uang negara lain. Kurs memainkan peranan penting dalam keputusan-keputusan pembelanjaan, karena kurs memungkinkan kita menerjemahkan hargaharga dari berbagai negara ke dalam satu bahasa yang sama" (Ekananda : 2014)

2) Faktor yang mempengaruhi nilai tukar (kurs)

Menurut Sukirno (2011 : 402), faktor-faktor yang mempengaruhi nilai tukar, yaitu :

a) Perubahan dalam citarasa masyarakat mempengaruhi corak konsumsi mereka.

b) Perubahan harga barang ekspor dan impor

c) Kenaikan harga umum (inflasi)

d) Perubahan Suku Bunga dan Tingkat Pengembalian Investasi.

e) Pertumbuhan Ekonomi 
3) Pengukuran Nilai Tukar

Pengukuran nilai tukar dalam penelitian ini menggunakan kurs tengah (sukirno : 2011), yaitu, yaitu: "Kurs tengah antara kurs jual dan kurs beli valuta asing terhadap mata uang nasional, yang telah ditetapkan oleh bank sentral pada saat tertentu".

Untuk mendapatkan kurs tengah sendiri, dihitung dengan menggunakan rumus sebagaiberikut : (Ekananda : 2014)

Kurs Tengah $=\frac{\mathrm{Kb}+\mathrm{Kj}}{2}$

Keterangan:

$\mathrm{Kb}:$ Kurs beli

$\mathrm{Kj}$ : Kurs jual

4) Hubungan Nilai Tukar dengan Neraca Perdagangan

Salah satu pengaruh neraca perdagangan adalah nilai tukar mata uang (kurs). Jumlah ekspor akan mengalami kenaikan dan neraca perdagangan mengalami surplus (dengan asumsi nilai impor tetap), pada saat mata uang suatu negara mengalami depresiasi (pelemahan) terhadap mata uang asing. Sehingga perubahan nilai tukar akan terus terjadi baik apresiasi maupun depresiasi akan mempengaruhi kegiatan ekspor dan impor. Sedangkan mata uang asing yang paling dominan adalah US\$.

f. Inflasi

1) Pengertian

- "Kenaikan harga barang-barang yang bersifat umum dan terus-menerus" (Sukirno :2011)

- $\quad$ "Kecenderungan meningkatnya harga barang dan jasa secara umum dan terusmenerus" (Natsir: 2014)

- $\quad$ "Suatu kejadian yang menggambarkan situasi dan kondisi di mana harga barangmengalami kenaikan dan nilai mata uang mengalami pelemahan" (Fahmi : 2014)

2) Faktor yang mempengaruhi Inflasi

faktor-faktor yang mempengaruhi inflasi yaitu: (Sukirno : 2011)

a) Inflasi Tarikan Permintaan.

b) Inflasi Desakan Biaya.

c) Inflasi Impor

3) Pengukuran Inflasi

Pengukuran Inflasi salah satunya menggunakan Indeks Harga Konsumen (IHK).

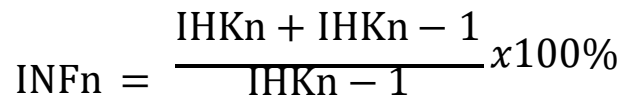


Keterangan:

IHKn : Indeks Harga Konsumen tahun ke-n

IHKn-1 : Indeks Harga Konsumen tahun sebelumnya

4) Hubungan Inflasi dengan Neraca Perdagangan

Inflasi mempunyai pengaruh besar terhadap ekspor. Pada saat harga-harga barang-barang dan jasa-jasa dalam negeri meningkat, permintaan akan mengalami penurunan sehingga barang-barang dan jasa-jasa tidak terserap di pasar dalam negeri, kelebihan ini juga tidak di jual di pasar luar negeri,karena harganya terlalu mahal, maka tindakan produsen adalah menurunkan tingkat produksi dalam jangka waktu tertentu sampai kondisi ekonomi normal. Jika ekspor mengalami penurunan disisi lain impor tetap akan terjadi jumlah eskpor lebih kecil dari impor, sehingga terjadi defisit neraca perdagangan.

g. Tingkat Suku Bunga

1) Pengertian

- perbandingan bunga atas jumlah pinjama" (Wiliam \& Juwita: 2012)

- balas jasa atau nilai yang diberikan oleh pihak yang meminjam kepada yang meminjamkan dana atau uang

- Suku bunga yang mencerminkan sikap atau stance kebijakan moneter yang ditetapkanoleh Bank Indonesia dan diumumkan kepada publik. (Siamat :2014)

- Suku Bunga SBI merupakan suku bunga yang dikeluarkan oleh bank sentral untuk mengontrol peredaran uang di masyarakat, dengan kata lain pemerintah melakukan kebijakan moneter. (Husnan: 2014)

- Harga dari penggunaan dana investasi. Tingkat suku bunga merupakan salah satu indikator dalam menentukan apakah seseorang akan melakukan investasi atau menabung. (Boediono: 2014)

2) Hubungan Tingkat Suku Bunga dengan Neraca Perdagangan

Jika tingkat suku bunga domestik lebih tinggi di banding tingkat suku bunga luar negeri akan menyebabkan terjadinya capital inflow, karena meningkatnya kebutuhan mata uang dalam negeri (rupiah). Tingkat suku bunga sebagai acuan dari penggunaan uang dalam jangka waktu tertentu. Pada saat rupiah terjadi apresiasi, maka harga ekspor mahal dan harga barang impor murah yang berdampak pada menurunnya net ekspor yang membuat neraca perdagangan menurun. (Boediono : 2017). Selain itu tingkat suku 
bunga mempengaruhi inflasi dan ekspor impor, tingkat suku bunga juga mempengaruhi investasi yang juga akan berdampak pada ekspor impor. Secara teori dapat di analisis bahwa tingkat suku bunga mempunyai hubungan negatif dengan neraca perdagangan.

\section{Penelitian Sebelumnya}

Wibowo tahun 2021, meneliti Analisis Pengaruh Nilai Tukar, Inflasi, Suku Bunga,Dan PDB Terhadap Neraca Perdagangan Indonesia dengan hasil Nilai Tukar signifikan dan berpengaruh positif terhadap neraca perdagangan di Indonesia, tingkat Inflasi signifikan dan berpengaruh negatif terhadap neraca perdagangan di Indonesia, tingkat suku bunga signifikan dan berpengaruh negatif terhadap neraca perdagangan di Indonesia, tingkat Produk Domestik Bruto berpengaruh signifikan dan berpengaruh terhadap neraca perdagangan di Indonesia dan nilai tukar, inflasi, suku bunga, dan PDB secara bersama-sama berpengaruh terhadap variabel dependen yaitu neraca perdagangan Indonesia.

Puspitasari tahun 2019, meneliti Analisis Faktor-Faktor Yang Mempengaruhi Neraca Perdagangan dengan hasil nilai tukar dolar AS tidak berpengaruh terhadap neraca perdagangan. Produk Domestik Bruto, investasi asing dan tingkat ekspor berpengaruh positifterhadap neraca perdagangan di Indonesia periode 1999 hingga 2017.

Asnawai \& Harniati tahun 2018, meneliti Pengaruh Produk Domestik Bruto, Suku Bunga, Kurs Terhadap Neraca Perdagangan Di Indonesia dengan hasil Produk Domestik Bruto (PDB) tidak berpengaruh terhadap neraca perdagangan di Indonesia. Suku bunga tidak berpengaruh terhadap neraca perdagangan di Indonesia. Dan Kurs berpengaruh positif signifikan terhadap neraca perdagangan di Indonesia.

Ginting tahun 2014 meneliti Perkembangan Neraca Perdagangan Dan Faktor- Faktor Yang Mempengaruhinya dengan hasil baik dalam jangka panjang maupun jangka pendek, konsumsi domestik dan nilai tukar riil berpengaruh negatif dan signifikan terhadap neraca perdagangan Indonesia, sedangkan variabel Investasi Asing Langsung dan PDB Negara lain berpengaruh positif. Nilai error correction model yang negatif dan signifikan menunjukkan adanya koreksi dari pergerakan variabel pada keseimbangan jangka panjang

3. Kerangka Pemikiran Dengan demikian kerangka pemikiran beberapa mengenai pengaruh variable PDB, Inflasi, Nilai Tukar dan Tingkat Suku Bunga terhadap Neraca Perdagangan digambarkan sebagai berikut 


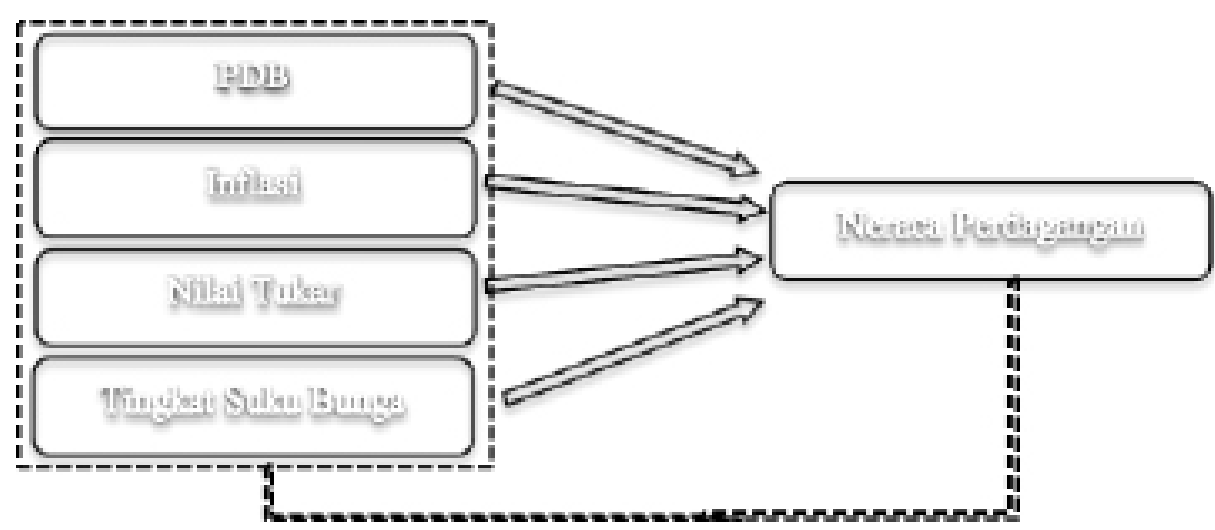

4. Perumusan Hipotesis

Berdasarkan perumusan masalah dan kajian empiris yang telah dilakukan sebelumnya, maka hipotesis yang diajukan dalam penelitian ini adalah:

a. Pengaruh PDB terhadap Neraca Perdagangan

PDB adalah pendapatan nasional berdasar konsep Produk Domestik Bruto, jika PDB suatu Negara mengalami pertumbuhan setiap periodenya menunjukkan bahwa tingkat pendapatan masyarakat bertambah, bertambahnya pendapatan akan meningkatkan dari sisi permintaan, dan akan diikuti dengan meningkatnya sisi penawaran (peningkatan barang dan jasa yang di produksi), jika barang dan jasa yang di produksi meningkat maka juga akan meningkatkan ekspor, jika asumsi impor tetap, maka akan membentuk surplus perdagangan suatu negara, secara ringkas semakin meningkatnya pendapatan nasional akan meningkatkan ekspor dan surplus neraca perdagangan. Hasil penelitian wibowo (2021), Puspitasari (2019), dan Ginting (2014), bahwa PDB berpengaruh positif terhadap Neraca Perdagangan, sedangkan Asnawi \& Harniati (2018) dalam penelitiannya menyatakan bahwa PDB tidak berpegaruh terhadap Neraca Perdagangan, berdasarkan hal tersebut di atas maka hipotesanya adalah :

Ha : diduga Produk Domestik Bruto berpengaruh positif terhadap Neraca Perdagangan

b. Pengaruh Inflasi terhadap Neraca Perdagangan

Inflasi adalah kecenderungan harga-harga naik, jika terjadi inflasi dalam suatu negara, dan jika tidak diikuti dengan peningkatan pendapatan secara signifikan, menyebabkan daya beli menurun, konsumsi masyarakat menurun, permintaan menurun, akibatnya barang-barang dan jasa-jasa di pasaran yang terbeli menjadi berkurang, jika ini berlangsung terus, produsen akan mengurangi produksinya, barang-barang dan jasa-jasa di pasaran berkurang, dampak terhadap ekspor juga berkurang, ekspor menurun, dan jika asumsi impor tetap menyebabkan neraca perdagangan menurun dan bahkan bisa 
defisit. Secara ringkas, jika terjadi inflasi, barang dan jasa yang diproduksi menurun, ekspor menurun dan neraca perdagangan bisa menjadi defisit. Sebab akibat ini juga telah di teliti oleh wibowo (2021) dengan hasil bahwa inflasi mempunyai pengaruh dan negatif terhadap Neraca Perdagangan, berdasar hal tersebut maka hopotes yang bisa di ambil adalah :

Ha : diduga Inflasi berpengaruh negatif terhadap Neraca Perdagangan

c. Pengaruh Nilai Tukar/Kurs terhadap Neraca Perdagangan

Kurs merupakan harga rupiah terhadap mata uang asing. Nilai satu mata rupiah yang ditukar dengan mata uang negara lain disebut nilai tukar rupiah, jika kurs rupiah semakin melemah maka setiap nilai mata uang asing jika dinilai dengan rupiah, nominalnya semakin besar, jika ini terjadi semakin nilai tukar melemah akan mendorong eksportir menambah jumlah barang-barang dan jasa-jasa untuk di ekspor, sehinggaekspor meningkat, jika asumsi impor tetap, akibatnya neraca perdagangan akan semakin meningkat (surplus perdagangan meningkat). Hal ini diperkuat dengan ahsil penelitian Wibowo (2021), asnawai \& Harniati (2018) dengan hasil bahwa ada pengaruh positif dan signifikan Kurs terhadap Neraca Perdagangan, maka hipotesa yang bisa di ambil adalah :

Ha: diduga Nilai Tukar berpengaruh positif terhadap Neraca Perdagangan

d. Pengaruh Tingkat Suku terhadap Konsumsi Agregate

Bunga balas jasa atau nilai yang diberikan oleh pihak yang meminjam kepada yang meminjamkan dana atau uang, jika tingkat suku bunga semakin naik (menurut teori investasi), maka jumlah investasi yang masuk atau kegiatan investasi akan mengalami penurunan, karena biaya modal akan mengalami kenaikan dan rate of return yang dipersyaratkan akan tinggi minimal sama atau lebih di banding biaya modal, sehingga kondisi seperti para investor enggan/tidak tertarik untuk melakukan investasi. Akibatnya pertumbuhan barang-barang dan jasa-jasa yang di hasilkan mengalami penurunan pengaruhnya pada ekspor juga megalami penurunan dan berimabas pada neraca perdagangan akan menurun dan bahkan mengalami defisit. Berdasar penelitian wibowo (2021) bahwa ada pengaruh negatif tingkat suku bunga terhadap neraca Perdagangan, dan penelitian asnawai \& Harniati (2018) yang menyatakan tidak ada pengaruh tingkat suku bunga terhadap Neraca Perdagangan, berdasarkan uraian tersebut, maka hipotesis yang bisa di ambil adalah :

Ha: Tingkat Suku Bunga berpengaruh negatif terhadap Konsumsi Agregate

e. Pengaruh PDB, Inflasi, Nilai Tukar dan Tingkat Suku Bunga secara simultan terhadap Neraca Perdagangan

Hasil penelitian wibowo (2021), Puspitasari (2019), dan Ginting (2014), 
bahwa dan Asnawi \& Harniati (2018) dalam penelitiannya menyatakan bahwa PDB, Inflasi, Nilai Tukar dan Tingkat Suku Bunga secara simultan berpengaruh terhadap Neraca Perdagangan, dari informasi tersebut, hipotesis yang bisa di ambil adalah :

Ha : PDB, Inflasi, Nilai Tukar dan Tingkat Suku Bunga secara simultan mempunyai pengaruh terhadap Neraca Perdagangan

\section{METODE PENELITIAN}

1. Jenis Penelitian Jenis penelitian ini merupakan penelitian kuantitatif bertujuan untuk memperoleh bukti empiris mengenai pengaruh variable PDB, Inflasi, Nilai Tukar dan Tingkat Suku Bunga terhadap Neraca Perdagangan, dan juga menguji hipotesis guna memperkuat atau bahkan menolak hipotesis. Data penelitian ini adalah data perkembangan variable tahun 2000-2019.

2. Metode pengumpulan data studi pustaka dan studi dokumentasi. Studi pustaka dilakukan dengan mengolah data, artikel, jurnal maupun media tertulis lain yang berkaitan dengan topik pembahasan dari penelitian ini. Studi dokumentasi adalah metode pengumpulan data dengan menggunakan data sekunder dari berbagai sumber seperti BPS, BI, Bank Dunia, Bappenas, dan sumber terkait yang digunakan untuk menyelesaikan masalah dalam penelitian ini seperti laporan harian, bulanan dan tahunan yang menjadi obyek penelitian.

3. Teknik Analisis Data Penelitian ini menggunakan metode penelitian kuantitatif dengan regresilinier berganda. $\mathrm{Y}=@+\beta \mathrm{X}_{1}+\beta \mathrm{X}_{2}+\beta \mathrm{X}_{3}+\beta \mathrm{X}_{4}+\mathrm{e}$ di mana $: \mathrm{Y}=$ Neraca Perdagangan,.@

$=$ Konstanta,. $\beta=$ Koefisien Regresi,. $X_{1}=\mathrm{PDB}, \mathrm{X}_{2}=$ Inflasi, $\mathrm{X}_{3}=$ Nilai Tukar, $\mathrm{X}_{4}=$ Tingkat Suku Bunga dan e $=$ Standar Eror

Definisi Operasional Variabel Variabel-variabel dalam penelitian ini dikelompokkan menjadi variabel dependen (terikat) dan variabel independen (bebas), sebagai berikut:

a. Variabel Dependent ; Neraca Perdagangan (Y), data Neraca Perdagangan telah disusun dan diperhitungkan serta merupakan catatan terhadap perubahan-perubahan maupun pergerakan data mulai tahun 2000 sampai dengan tahun 2019.

b. Variabel Indipendent ;

1) PDB $\left(\mathrm{X}_{1}\right)$, diukur dari Jumlah Pendapatan Nasional (PDB) dalam 1 periode selama 20tahun

2) Inflasi $\left(X_{2}\right)$ Inflasi adalah suatu proses meningkatnya harga-harga secara umum dan terus-menerus berkaitan dengan mekanisme pasar yang dapat disebabkan oleh berbagai faktor. Inflasi dalam penelitian ini adalah inflasi per tahun yang diukur dengan satuan prosentase (\%) 
3) Nilai Tukar $\left(\mathrm{X}_{4}\right)$ adalah kurs rupiah terhadap US $\$$ dalam 1 periode selama 20 tahun

4) Tingkat Suku bunga $\left(X_{3}\right)$ adalah adalah suku bunga kebijakan yang mencerminkan sikap atau stance kebijakan moneter yang ditetapkan oleh bank Indonesia (BI rate)-BI 7-day (Reverse) Repo Rate dan diumumkan kepada publik per bulan yang diukur dengan satuan prosentase $(\%)$

\section{HASIL PENELTIAN DAN PEMBAHASAN}

\section{Uji Normalitas Kolmogorov Smirov (Uji K-S)}

Pengujian normalitas dilakukan dengan maksud untuk melihat distribusi normal atau tidaknya data yang dianalisis. Pengujian ini untuk melihat apakah dalam model regresi, variabel pengganggu atau residual memiliki distribusi normal. Hipotesis yang digunakan adalah data residual tidak berdistribusi normal $\left(\mathrm{H}_{0}\right)$ dan data residual berdistribusi normal (Ha).

Dari olah data menunjukkan bahwa distribusi dari model regresi adalah normal dan memenuhi uji normalitas karena nilai Asymp.Sig (2-tailed) variabel residual $(0,200)$ berada diatas 0,05. (Probabilitas $>0,05$ )

\section{Tabel 1}

Hasil Pengujian Normalitas One-Sample Kolmogorov-Smirnov Test

\begin{tabular}{llc}
\hline & \multicolumn{1}{c}{$\mathrm{N}$} & Unstandardized Residual \\
\cline { 3 - 3 } & Mean & 20 \\
\hline Normal & Std. Deviation & .0000000 \\
Parameters ${ }^{\mathrm{a}, \mathrm{b}}$ & Sbsolute & .01546293 \\
Most Extreme & Abs & .094 \\
Differences & Positive & .094 \\
Negative & & -.075 \\
Test Statistic & & .094 \\
Asymp. Sig. (2-tailed) & $.200^{\mathrm{c}, \mathrm{d}}$ \\
\hline
\end{tabular}

Sumber : data di olah dengan SPSS 23-2019

\section{Uji Autokorelasi}

Uji autokorelasi bertujuan untuk mengetahui apakah dalam model regresi linear ada korelasi antara kesalahan pengganggu pada periode t dengan kesalahan pengganggu pada periode t-1. Apabila terjadi korelasi maka ada autokorelasi. Autokorelasi muncul karena observasi yang berurutan sepanjang waktu berkaitan satu sama lainnya. 
Tabel 2

Hasil Pengujian Autokorelasi

\begin{tabular}{cccccc}
\hline Model & $\mathrm{R}$ & $\begin{array}{c}\mathrm{R} \\
\text { Square }\end{array}$ & $\begin{array}{c}\text { Adjusted R } \\
\text { Square }\end{array}$ & Std.Error of the Estimate & $\begin{array}{c}\text { Durbin- } \\
\text { Watson }\end{array}$ \\
\hline 1 & $.839^{\mathrm{a}}$ & .703 & .624 & 9125.48949 & 1.882 \\
\hline
\end{tabular}

Sumber : data di olah dengan SPSS 23-2019

Hasil pengujian diperoleh nilai DW sebesar 1,882 berada di antara $\mathrm{du}<\mathrm{d}<$ 4-du $(1,67634<1,882<2.32366)\left(\mathrm{N}_{20}, \mathrm{df}_{1}: 4 \mathrm{df}_{2}: 15 \mathrm{dl}: 0,99755 \mathrm{du}: 1,67634\right) \mathrm{Hal}$ ini bahwa tidak terjadi autokorelasi antara variabel independen sehingga model regresi layak untuk digunakan.

\section{Uji Multikolinearitas}

Uji multikolinearitas bertujuan untuk menguji apakah model regresi ditemukan adanya korelasi antara variabel bebas. Model regresi yang baik seharusnya tidak terjadi korelasi diantara variabel independen. Multikolinearitas dapat dilihat dari nilai tolerance dan Variance Inflation Factor (VIF). Tolerance mengukur variabilitas variabel independen yang terpilih yang tidak dijelaskan oleh variabel independen lainnya, sehingga nilai tolerance yang rendah sama dengan nilai VIF tinggi, karena VIF $=1$ / tolerance. Data dikatakan bebas dari masalah multikolinearitas apabila memiliki nilai tolerance $\geq 0,10$ atau sama dengan nilai $\mathrm{VIF} \leq 10$

Tabel 3

Hasil Pengujian Multikolinearitas

\begin{tabular}{lccccc}
\hline \multirow{2}{*}{ Model } & \multicolumn{2}{c}{$\begin{array}{c}\text { Unstandardized } \\
\text { Coefficients }\end{array}$} & $\begin{array}{c}\text { Standardized } \\
\text { coefficients }\end{array}$ & \multicolumn{2}{c}{ Collinearity Statistics } \\
\cline { 2 - 6 } & $\mathrm{B}$ & Std. Error & Beta & Tolerance & VIF \\
\hline 1 (Constant) & 73007.482 & 14924.413 & & & \\
PDB & -9.029 & 2.686 & -.749 & .398 & 2.511 \\
Inflasi & -1405.593 & 775.910 & -.363 & .493 & 2.028 \\
Kurs & -2.005 & 1.493 & -.270 & .487 & 2.052 \\
Bunga & -680.116 & 585.536 & -.200 & .668 & 1.496 \\
\hline
\end{tabular}

Sumber : data di olah dengan SPSS 23-2019

Hasil perhitungan nilai tolerance menunjukkan bahwa tidak ada variabel independen yang mempunyai nilai toleransi $\leq 0,10$ dan tidak ada nilai VIF $\geq 10$, sehingga dapat disimpulkan bahwa model regresi pada penelitian ini tidak terjadi multikolinearitas, data mempunyai distribusi normal dan model regresi layak digunakan. 


\section{Uji Heteroskedastisitas}

Uji heteroskedastisitas bertujuan untuk menguji apakah dalam model regresi terjadi ketidaksamaan variance dari residual satu pengamatan ke pengamatan lain. Pengujian dilakukan dengan uji Glejser yaitu dengan meregres variabel independen terhadap nilai absolute residual. Apabila variabel independen signifikan secara statistik memengaruhi variabel dependen, maka ada indikasi terjadi heteroskedastisitas. Kriteria yang biasa digunakan untuk menyatakan apakah terjadi heteroskedastisitas atau tidak diantara data pengamatan dapat dijelaskan dengan menggunakan koefisien signifikansi. Koefisien signifikansi harus dibandingkan dengan tingkat signifikansi yang ditetapkan sebelumnya ( $\alpha=5 \%$ ). Apabila koefisien signifikansi (nilai probabilitas) lebih besar dari tingkat signifikansi yang ditetapkan, maka dapat disimpulkan tidak terjadi heteroskedastisitas

\section{Tabel 4}

Hasil Pengujian Heteroskedastisitas

\begin{tabular}{ccccccc}
\hline \multirow{2}{*}{ Model } & \multicolumn{2}{c}{$\begin{array}{c}\text { Unstandardized } \\
\text { Coefficients }\end{array}$} & $\begin{array}{c}\text { Standardized } \\
\text { Coefficients }\end{array}$ & \multirow{2}{*}{$\mathrm{t}$} & Sig. \\
\cline { 3 - 5 } & & $\mathrm{B}$ & Std. Error & Beta & & \\
\hline \multirow{2}{*}{1} & (Constant) & 73007.482 & 14924.413 & & 4.892 & .000 \\
& PDB & -9.029 & 2.686 & -.749 & -3.362 & .004 \\
& Inflasi & -1405.593 & 775.910 & -.363 & -1.812 & .049 \\
& Kurs & -2.005 & 1.493 & -.270 & -1.343 & .199 \\
& Bunga & -680.116 & 585.536 & -.200 & -1.162 & .264 \\
\hline
\end{tabular}

Sumber : data di olah dengan SPSS 23

Menunjukkan bahwa tidak ada satupun variabel independen yang signifikan secara statistik memengaruhi variabel dependen nilai absolute residual (abs_res). Hal ini terlihat dari probabilitas signifikansi di atas tingkat kepercayaan 5\%.

\section{Analisis Regresi Berganda}

Analisis regresi linear berganda digunakan untuk mengetahui pengaruh variable PDB, Inflasi,Nilai Tukar dan Tingkat Suku Bunga terhadap Neraca Perdagangan

Berdasar table 4 maka persamaan regresi bergandanya : Neraca Perdagangan $=73.007,482$-9,029 PDB - 1.405,593 Inflasi - 2,005 Kurs - 680.116 Suku bunga + e Konstanta

Ini berarti jika semua variabel bebas memiliki nilai nol (0) maka nilai variabel terikat (Beta)sebesar 73.007,482

a. PDB $\left(\mathrm{X}_{1}\right)$ terhadap Neraca Perdagangan $(\mathrm{Y})$

Nilai koefisien PDB sebesar - 9,029. Hal ini mengandung arti bahwa setiap 
kenaikan PDBsatu satuan (\%) maka variabel Neraca Perdagangan (Y) akan turun sebesar 9,029 dengan asumsi bahwa variabel bebas yang lain dari model regresi adalah tetap.

b. Inflasi $\left(\mathrm{X}_{2}\right)$ terhadap Neraca Perdagangan (Y)

Nilai koefisien Inflasi sebesar - 1.405,593 dan bertanda negatif, ini menunjukkan bahwa harga mempunyai hubungan yang berlawanan arah dengan Neraca Perdagangan. Hal ini mengandung arti bahwa setiap kenaikan harga satu satuan (\%) maka Neraca Perdagangan akan turun sebesar 1.405,593 dengan asumsi bahwa variabel bebas yang lain dari model regresi adalah tetap

c. $\quad \operatorname{Kurs}\left(\mathrm{X}_{3}\right)$ terhadap Neraca Perdagangan $(\mathrm{Y})$

Nilai koefisien Kurs untuk variabel $\mathrm{X}_{3}$ sebesar -2,005 dan bertanda negatif, ini menunjukkan bahwa Kurs mempunyai hubungan yang berlawanan dengan Neraca Perdagangan. Hal ini mengandung arti bahwa setiap kenaikan Kurs satu satuan (\%) maka Neraca Perdagangan akan naik sebesar -2,005 dengan asumsi bahwa variabel bebas yang lain dari model regresi adalah tetap

d. Tingkat Suku Bunga $\left(\mathrm{X}_{4}\right)$ terhadap Neraca Perdagangan (Y)

Nilai koefisien Tingkat Suku Bunga sebesar-680.116 dan negatif, ini menunjukkan bahwa Tingkat Suku Bunga mempunyai hubungan yang berlawanan dengan Neraca Perdagangan. Hal ini mengandung arti bahwa setiap kenaikan Tingkat Suku Bunga satu satuan maka Neraca Perdagangan akan turun sebesar 680.116 dengan asumsi bahwa variabel bebas yang lain dari model regresi adalah tetap

\section{Uji Determinasi}

Berdasarkan Tabel D.5 hasil uji koefisien determinasi terlihat bahwa nilai Adjusted R Square sebesar 0,624 yang menunjukkan presentase bahwa berpengaruh pengaruh variable independen PDB, Inflasi, Nilai Tukar dan Tingkat Suku Bunga terhadap variable dependen Neraca Perdagangan sebesar 62,4 \% sisanya dipengaruhi faktor lain di luar model sebesar 37,6\%.

Tabel 5

Hasil Pengujian Autokorelasi

\begin{tabular}{cccccc}
\hline Model & $\mathrm{R}$ & $\begin{array}{c}\mathrm{R} \\
\text { Square }\end{array}$ & $\begin{array}{c}\text { Adjusted R } \\
\text { Square }\end{array}$ & $\begin{array}{c}\text { Std.Error of the } \\
\text { Estimate }\end{array}$ & $\begin{array}{c}\text { Durbin- } \\
\text { Watson }\end{array}$ \\
\hline 1 & $.839^{\mathrm{a}}$ & .703 & .624 & 9125.48949 & 1.882 \\
\hline
\end{tabular}

Sumber : data di olah dengan SPSS 23-2019

\section{Uji Simultan (Uji F)}

Berdasarkan Tabel 6 hasil analisis data uji $\mathrm{F}$ diperoleh sig $0,001^{\mathrm{b}}<0,05$ dan diperoleh nilai $F_{\text {hitung }} 8,897>$ nilai $F_{\text {tabel }} 2,852$ sehingga dapat disimpulkan bahwa 
Ho ditolak Ha diterima artinya seluruh variabel independen (PDB, Inflasi, Nilai Tukar dan Tingkat Suku Bunga) secara bersama-sama berpengaruh terhadap variabel dependen Neraca Perdagangan.

\section{Tabel 6}

Hasil Pengujian Simultan

\begin{tabular}{lccccc}
\hline \multicolumn{1}{c}{ Model } & Sum of Squares & df & Mean Square & F & Sig. \\
\hline Regression & 2963714444.173 & 4 & 740928611.043 & 8.897 & $.001^{\text {b }}$ \\
Residual & 1249118375.225 & 15 & 83274558.348 & & \\
\hline Total & 4212832819.398 & 19 & & & \\
\hline
\end{tabular}

Sumber : data di olah dengan SPSS 23

F Hitung: $\quad 8,897>$ F Tabel $\left(\alpha: 0,05, \mathrm{df}_{1}: 4, \mathrm{df}_{2}: 16\right): 2,852$

\section{UJI REGRESI PARSIAL (UJI T)}

Uji statistik t pada dasarnya menunjukkan seberapa jauh pengaruh satu variabel independen secara individual dalam menerangkan variasi variabel dependen. berdasarkan data Tabel D.7. dapat diterangkan sebagai berikut:

\section{Tabel 7}

Hasil Pengujian Regresi Parsial

\begin{tabular}{llrrrrr}
\hline \multirow{2}{*}{ Model } & \multicolumn{2}{c}{$\begin{array}{l}\text { Unstandardized } \\
\text { Coefficients }\end{array}$} & \multicolumn{2}{c}{$\begin{array}{c}\text { Standardized } \\
\text { Coefficients }\end{array}$} & \multirow{2}{*}{$\mathrm{t}$} & \multirow{2}{*}{ Sig. } \\
\cline { 3 - 5 } & \multicolumn{1}{c}{$\mathrm{B}$} & \multicolumn{1}{c}{ Std. Error } & Beta & & \\
\hline 1 & (Constant) & 73007.482 & 14924.413 & & 4.892 & .000 \\
& PDB & -9.029 & 2.686 & -.749 & -3.362 & .004 \\
& Inflasi & -1405.593 & 775.910 & -.363 & -1.812 & .049 \\
Kurs & -2.005 & 1.493 & -.270 & -1.343 & .199 \\
Bunga & -680.116 & 585.536 & -.200 & -1.162 & .264 \\
\hline
\end{tabular}

Sumber : data di olah dengan SPSS 23

Uji t digunakan untuk mengetahui apakah variabel-variabel independen secara parsial berpengaruh nyata atau tidak terhadap variabel dependen. Derajat signifikansi yang digunakan adalah 0,05 . Apabila nilai signifikan lebih kecil dari derajat kepercayaan maka kita menerima hipotesis alternatif, yang menyatakan bahwa suatu variabel independen secara parsial mempengaruhi variabel dependen. 
a. $\quad$ PDB $\left(\mathrm{X}_{1}\right)$ terhadap Neraca Perdagangan (Y)

Terdapat nilai sig 0,004 lebih kecil dari nilai probabilitas $0,05(0,004<0,05)$. makaHa diterima dan Ho ditolak. Variabel $X_{1}$ mempunyai $t_{\text {hitung }}$ yakni $-3,362$ dengan $\mathrm{t}_{\text {tabel }}=1.75305$ Jadi $\left(\mathrm{t}_{\text {hitung }}>\mathrm{t}_{\text {tabee }}\right)$ bahwa variabel $\mathrm{X}_{1}$ memiliki kontribusi terhadap $Y$. Nilai t negatif menunjukkan bahwa variabel $\mathrm{X}_{1}$ mempunyai hubungan berlawanan dengan Y. Jadi PDB memiliki pengaruh negatif signifikan terhadap Neraca Perdagangan.

b. Inflasi $\left(\mathrm{X}_{2}\right)$ terhadap Neraca Perdagangan (Y)

Terdapat nilai sig 0,049 lebih kecil dari nilai probabilitas $0,05(0,049<0,05)$. makaHa diterima dan Ho ditolak. Variabel $\mathrm{X}_{2}$ mempunyai $\mathrm{t}_{\text {hitung }}$ yakni $-1,812$ dengan $t_{\text {tabel }}= \pm 1.75305$ Jadi $\left(t_{\text {hitung }}>-t_{\text {tabel }}\right)$ bahwa variabel $X_{2}$ memiliki kontribusi terhadap Y. Nilai $t$ negatif menunjukkan bahwa variabel $\mathrm{X}_{2}$ mempunyai hubungan berlawanan dengan $Y$.

Jadi Inflasi memiliki pengaruh negatif dan signifikan terhadap Neraca Perdagangan

c. $\quad$ Kurs $\left(\mathrm{X}_{3}\right)$ terhadap Neraca Perdagangan $(\mathrm{Y})$

Terdapat nilai sig 0,199 lebih besar dari nilai probabilitas $0,05 \quad(0,199$ $>0,05)$. maka Ha ditolak dan Ho diterima. Variabel $X_{3}$ mempunyai $t_{\text {hitung }}$ yakni $-1,343$ dengan $\mathrm{t}_{\text {tabel }}=1.75305$ Jadi $\left(\mathrm{t}_{\text {hitung }}<\mathrm{t}_{\text {tabel }}\right)$ bahwa variabel $\mathrm{X}_{1}$ tidak memiliki kontribusi terhadap Y. Nilai t negatif menunjukkan bahwa variabel $X_{3}$ mempunyai hubungan berlawanan dengan Y. Jadi Kurs tidak memiliki pengaruh yang signifikan terhadap Neraca Perdagangan

d. Tingkat Suku Bunga $\left(\mathrm{X}_{4}\right)$ terhadap Neraca Perdagangan $(\mathrm{Y})$

Terdapat nilai sig 0,264 lebih besar dari nilai probabilitas $0,05(0,264>$ 0,05). maka Ha ditolak dan Ho diterima. Variabel $X_{4}$ mempunyai $t_{\text {hitung }}$ yakni -1.162 dengan $\mathrm{t}_{\text {tabel }}=1.75305$ Jadi $\left(\mathrm{t}_{\text {hitung }}<\mathrm{t}_{\text {tabel }}\right)$ bahwa variabel $\mathrm{X}_{1}$ tidak memiliki kontribusi terhadap Y. Nilai t negatif menunjukkan bahwa variabel $\mathrm{X}_{3}$ mempunyai hubungan berlawanan dengan Y. Jadi Tingkat Suku Bunga tidak memiliki pengaruh yang signifikan terhadap Neraca Perdagangan

\section{Pembahasan}

a. Pengaruh PDB terhadap Neraca Perdagangan

Dari hasil uji t bahwa PDB memiliki kontribusi terhadap Neraca Pedagangan. Nilait negatif menunjukkan bahwa PDB mempunyai hubungan berlawanan dengan Neraca Perdagangan. Jadi PDB memiliki pengaruh negatif signifikan terhadap Neraca Perdagangan. Maka hipotesa Ho di tolak dan hipotesa Ha diterima sebagian, karena Ha menyatakan bahwa diduga ada pengaruh positif PDB terhadap Neraca Pembayaran, dan hasil analisis menyebutkan ada pengaruh negatif PDB terhadap Neraca Pembayaran. Hasil ini berbeda seperti yang diteliti oleh wibowo (2021), Puspitasari (2019), dan Ginting (2014) dengan hasil 
penelitiannya bahwa PDB berpengaruh positif terhadap Neraca Perdagangan, sedangkan Asnawi \& Harniati (2018) dalam penelitiannya menyatakan bahwa PDB tidak berpegaruh terhadap Neraca Perdagangan

b. Pengaruh Inflasi terhadap Neraca Perdagangan

Dari hasil uji hipotesa bahwa Ho di tolak dan Ha diterima, artinya ada pengaruh negatif dan signifikan Inflasi terhadap Neraca Perdagangan, ini sejalan dengan penelitian yang telah dilakukan wibowo (2021). Jika terjadi inflasi maka hargaharga akan mengalamikenaikan, akibatnya permintaan akan barang-barang dan jasa-jasa akan cenderung menurunkarena kenaikan harga tidak di ikuti dengan kenaikan pendapatan yang seimbang. Dampaknya barang-barang dan jasa-jasa yang diproduksi mengalami kelebihan penawaran,jika inflasi terus berlangsung kecenderungan produsen mengurangi produksinya, selain karena penurunan permintaan karena harga naik, di sisi lain jug adanya kenaikan bahan baku. Akibat berkurangnya produksi pengaruhnya pada jumlah barang-barang yang di ekspor juga akan mengalami penurunan. Jika asumsi impor tetap dan ekspor mengalami penurunan menyebabkan neraca perdagangan akan mengalami penurunan dan bahkan bisa terjadi defisit neraca perdagangan.

c. Pengaruh Kurs terhadap Neraca Perdagangan

Dari hasil uji hipotesa bahwa Ho di terima dan Ha ditolak, artinya tidak ada pengaruh Kurs terhadap Neraca Perdagangan, ini tidak sejalan dengan penelitian yang telahdi lakukan wibowo (2021), asnawai \& Harniati (2018) dengan hasil bahwa ada pengaruh positif dan signifikan Kurs terhadap Neraca Perdagangan, tetapi sesuai dengan hasil penelitian Puspitasai (2019) bahwa tidak ada pengaruh kurs terhadap Neraca Perdagangan. Jika kurs dalam suatu negara melemah, maka mendorong ekportir akan menambah jumlah barang-barang dan jasa-jasa yang di ekspor, karena harga yang sama dengan mata uang asing, jika nanti dibayarkan lagi ke Indonesia dengan uang rupiah, jumlahnya akan lebih besar secara nominal sebelum nilai mata uang (rupiah) melemah.

d. Pengaruh Tingkat Suku Bunga terhadap Neraca Perdagangan

Dari hasil hipotesa bahwa Ho diterima dan Ha di tolak, artinya tidak ada pengaruh antara tingkat suku bunga dengan Neraca Perdagangan. ini tidak sejalan dengan penelitian yang telah di lakukan wibowo (2021) bahwa ada pengaruh negatif tingkat suku bunga terhadap neraca Perdagangan, tetapi sesuai dengan penelitian asnawai \& Harniati (2018) yang menyatakan tidak ada pengaruh tingkat suku bunga terhadap Neraca Perdagangan. Jika tingkat suku bunga naik (menurut teori investasi), maka jumlah investasi yang masuk atau kegiatan investasi akan mengalami penurunan, karena biaya modal akan mengalami kenaikan dan rate of return yang dipersyaratkan akan tinggi minimal sama atau lebih di banding biaya modal, sehingga kondisi seperti para investor enggan/tidak tertarik untuk melakukan investasi. Akibatnya pertumbuhan barang-barang dan jasa-jasa yang di hasilkan mengalami penurunan pengaruhnya pada ekspor juga megalami 


\section{Ilham Tri Murdo, Junaidi Affan}

penurunan dan berimbas pada neraca perdagangan.

e. Pengaruh PDB, Inflasi, Kurs dan Tingkat Suku Bunga secara simultan Terhadap Neraca Perdagangan

\section{E. KESIMPULAN}

Berdasarkan hasil penelitian secara keseluruhan dapat diambil kesimpulan sebagai berikut: Produk Domestik Bruto (PDB) berpengaruh negatif dan signifikan terhadap Neraca Perdagangan, Inflasi berpengaruh negatif dan signifikan terhadap terhadap Neraca Perdagangan Kurs tidak berpengaruh dan tidak signifikan terhadap Neraca Perdagangan, Tingkat Suku Bunga tidak berpengaruh dan tidak signifikan terhadap Neraca Perdagangan, Produk Domestik Bruto (PDB), Inflasi, Kurs dan Tingkat Suku Bunga secara bersama-sama (simultan) berpengaruh dansignifikan terhadap Neraca Perdagangan

\section{DAFTAR PUSTAKA}

Adiningsih, Adi, (2002). Indonesia Menjelang AFTA 2002. Ekonomi Pembangunan 2002,VII(7). Ali Purwito, Indriani, (2015) Ekspor, Impor, Sistem Harmonisasi, Nilai Pabean, Dan Pajak Dalam

Kepabeanan, Edisi 1, Mitra Wacana Media, Bogor, Jawa Barat

Andi Susilo, (2013), Panduan Pintar Ekspor Impor, Trans Media, Jakarta

Asnawi, \& Hasniati. (2018). Pengaruh Produk Domestik Bruto, Suku Bunga, Kurs Terhadap Neraca Perdagangan Di Indonesia.. Jurnal Ekonomi Regional Unimal Volume 01 Nomor 01 April 2018 E-ISSN : 2615-126X URL: https://ojs.unimal. ac.id/index.php/ekonomi_regional

Bappenas, (2009) https://www.bappenas.go.id/files/4413/5027/4149/ringkasaneksekutifhandbook-2009060509 20090518105300 0.pdf

Berata, I Komang Oko, (2013). Panduan Praktis Ekspor Impor. Bekasi: Raih Asa Sukses.

Boediono. (2002). The international monetary fund support program in Indonesia: Comparing implementation under three Presidents. Bulletin of Indonesian Economic Studies. https://doi.org/10.1080/00074910215533

Boediono. (2017). Ekonomi Moneter. In Seri Sinopsis Pengantar Ilmu Ekonomi No. BI, (2020), Laporan Perekonomian Indonesia, Jakarta, http://www.BI.go.id

Boediono. 2013. Ekonomi Makro. BPFE, Yogyakarta .

Boediono, (2016), Ekonomi Indonesia Dalam Lintasan Sejarah, Cetakan III, PT Mizan Pustaka,Bandung. 
BPS, Laporan Perekonomian 2020 Jakarta. http://www.BPS.go.id

CenturyManifesto for EconomicDevelopment. History of Economics Review. https:// doi.org/10.1080/18386318.2014.11681258

Dahlan, Siamat. (2015). Manajemen Lembaga Keuangan "Kebijakan Moneter dan Perbankan",Jakarta: Fakultas Ekonomi Universitas Indonesia

Dewi Mustika Rahmawati (2014). Pengaruh Kurs Dan GDP Terhadap Neraca PerdaganganIndonesia Tahun 1980-2012. http://journal.unnes.ac.id/sju/index. php./edaj

Ekananda, Mahyus, (2014). Ekonomi Internasional. Jakarta, Erlangga.Fahmi, I. (2014) Analisis Laporan Keuangan, Alfabeta, Bandung

Ginting, Ari, Mulianta, (2014), Perkembangan Neraca Perdagangan Dan FaktorFaktor YangMempengaruhinya, Buletin Ilmiah Litbang Perdagangan, VOL.8 NO. 1, JuLi 2014

Husnan, Suad, (2015), Dasar-Dasar Teori Portofolio dan Analisis Sekuritas. (Edisi 5). Yogyakarta: UPPN STIM YKPN

M. Agus Erwanto, 2018, Analisis Faktor-Faktor Yang Mempengaruhi Konsumsi Masyarakat DiIndonesia Tahun 2009.I-2017.III, Universitas Muhammadiyah Surakarta.

Madura, J. (200)3. "Financial Institution and Markets". 6th edition. South western : Division ofThomsom Learning.

Marseto, Pengaruh Suku Bunga Indonesia (SBI) Terhadap Inflasi, Kurs Rupiah, Dan PertumbuhanEkonomi, Jurnal Ilmiah

Mankiw, Gregory N. (2014). Principles of Economics, Pengantar Ekonomi Makro, EdisiKetiga.Salemba Empat, Jakarta

Meier, G.M., (1996), Dalam Juniartha R. Pinem (2009): Analisis PengaruhEkspor, Impor, KursNilai Tukar Rupiah Terhadap Cadangan DevisaIndonesia, USU Reposirtory.

Rahmani Astuti. Bandung: KaifaMerdeka.com, (2019), https://www.merdeka.com/ uang/ini-penyebab-defisit-neraca-perdagangan-versi-faisal-basri.html

Nanga, M. (2001). Makro Ekonomi Teori, Masalah, dan Kebijakan. Jakarta: Rajawali Pers.Nezky, M. (2013). The Impact of US Crisis on Trade and Stock Market in Indonesia.

Nenden Yushinta Puri, Ima Amaliah dan Westu Riani (2019). Pengaruh Inflasi, Suku Bunga, PDB,Nilai Tukar, Dan Krisis Ekonomi Terhadap Neraca Perdagangan Indonesia Periode 1995- 2017. Prodi Ilmu Ekonomi Dan Bisnis, Universitas Bandung, Jl.Tamansari No. 1 Bandung 40116 
Nancy Nopeline dan Maria Fransiska Siahan (2020). Pengaruh Nilai Tukar Dan Inflasi Terhadap Neraca Perdagangan Di Indonesia 2008-2018. Volume. 01. No 01 Fakultas Ekonomi Universitas HKBP Nommensen, Medan.

Nopirin, (2014), Ekonomi Moneter Buku 1, Edisi 1, Cetakan 14. BPFE, Yogyakarta. Nopirin, (2013), Ekonomi Moneter Buku 2. BPFE, Yogyakarta

Perrotta, C. (2014). Thomas Mun's England's Treasure by Forraign Trade: the 17 th

Porter, M. (1990). Competitive Advantage of Nations. Competitive Intelligence Review. https://doi.org/10.1002/cir.3880010112

Sukirno, Sadono, (2007). Makroekonomi Modern. Jakarta : PT Raja Grafindo Persada Sukirno, Sadono. (2016). Teori Pengantar Makroekonomi. In Rajawali Press.

Sugema, I. (2005). The Determinants of Trade Balance and Adjustment to the Crisis in Indonesia.

Centre for International Economix Studies.

Todaro, M. P., \& Smith, S. C. (2006). Pembangunan Ekonomi (Edisi Kesembilan). In Diterjemahkan oleh Drs Haris Munandar, MA dan Puji AL, SE dari Buku Economic Development Ninth Edition. Jakarta: Erlangga.

Undang-undang (UU) Nomor 17 Tahun 2006 tentang Perubahan atas Undang-Undang Nomor 10Tahun 1995 tentang Kepabeanan.

Wibowo, Seno (2021), Analisis Pengaruh Nilai Tukar, Inflasi, Suku Bunga, Dan PDB TerhadapNeraca Perdagangan Indonesia, Universitas Islam Indonesia, Yogyakarta

William, T., \& Juwita, R. (2012). Pengaruh Suku Bunga, Inflasi, Dan Pendapatan NasionalTerhadap Nilai Tukar Rupiah Tahun 2008-2012. Jurnal Manjemen. 